\begin{tabular}{lll}
\hline AECORDS OF PHARMACEUTICAL \\
AND BIOMEDICAL SCIENCES
\end{tabular}

\title{
Phytochemical, antioxidant and anti-inflammatory screening of the Egyptian Ulva lactuca methanolic extract
}

\author{
Doaa A. Ghareeb ${ }^{\text {a,b,c }}$, Hala H. Zaatout ${ }^{d^{*}}$, Amany Ismael ${ }^{\mathrm{e}}$, Alshimaa Abd-Elgwad Al,c $^{\text {a,b }}$ \\ ${ }^{a}$ Biochemistry, Department of Biochemistry, Faculty of Science, Alexandria University, Egypt; ${ }^{b}$ Biological \\ screening and preclinical trial lab, Department of Biochemistry, Faculty of Science, Alexandria University, \\ Egypt; ${ }^{c}$ Pharmaceutical and Fermentation Industries Development Centre, City of Scientific research and \\ technological application, Egypt; ${ }^{d}$ Department of Pharmacognosy, Faculty of Pharmacy, Alexandria \\ University, Egypt, 21521; ${ }^{e}$ Oceanography Science, Faculty of Science, Alexandria University, Egypt
}

Received on: 19.04. 2019

Revised on: 01. 05. 2019

Accepted on: 09. 05. 2019

Correspondence Author:

Tel:+ 201001842369

E-mail address:

halamsan@hotmail.com, hala.zatout@alexu.edu.eg

\begin{abstract}
Ulva lactuca is widespread green alga. In some regions, it is used in nutrition. Its nutrients include iron, protein, iodine, vitamins (A, B1 and C) and trace elements. Ulva extracts showed potential antibacterial, hypolipidemic, cardioprotective and chemoprotective activities. Phytochemical investigation of the Egyptian Ulva lactuca methanolic crude extract/fractions were assessed by measuring total phenolics, flavonoids, alkaloids, carbohydrates, lipids, proteins and amino acids content. Biologically guided fractionation of plants or seaweeds extracts is considered the first step in drug discovery. So, the algal crude extract was fractionated then in vitro bioscreened for the determination of diphenylpicrylhydrazyl (DPPH) antioxidant, NO radical scavenging and antiinflammatory activities. Results showed that water fraction was the most active fraction so it was subjected to further phytochemical investigation. Phenolic content, detected from HPLC, play a role in the antioxidant activity. Finally, it can be concluded that Ulva water fraction is effective candidate to be used in the treatment of oxidative stress and related disorders.
\end{abstract}

Keywords: Green algae, Ulva lactuca, phenolic, DPPH, antioxidant activity

\section{Introduction:}

Green algae are the most diverse group of algae with more than 7000 species growing in a variety of habitats. Ulva lactuca is a widespread macro alga occurring at all levels of the intertidal zone. In some regions, it is consumed in nutrition. Its nutrients include iron, protein (15\%), iodine, vitamins (A, B1 and $\mathrm{C}$ ) and trace elements. Tunisian algae powder was characterised by a high content of fibres, minerals, proteins and lipids (Yaich et al., 2011). Ulva lactuca showed potential antibacterial activity (Saritha et al., 2013); (Kim et al., 2007). Because of its antibacterial properties, it has been recommended in treating skin irritations and burns
(Apaydın et al., 2010). Ulvan extracted from the algae showed cytotoxic activity (Thanh et al., 2016) while the aqueous ethanolic extract showed chemoprotective effect (Delgado-Roche et al., 2019). Ethanolic extract also showed hypolipidemic and cardioprotective effects (Kammoun et al., 2018). Ulva lactuca has a great potential antioxidant activity because it is considered as a potential rich source of natural colorant (El-Baky et al., 2008). Algal extracts eliminated the harmful effects of oxidative stress induced by $\gamma$-irradiation (Alam et al., 2016). Reactive oxygen species (ROS) are capable of causing damage to biomolecules, such as nucleic acids, lipids, proteins and other cellular 
constituents. This is associated with various chronic diseases (Cooke et al., 2002). For these reasons, antioxidant compounds are widely used to minimize oxidative damage. Synthetic antioxidants such as butylated hydroxyanisol (BHA) and butylated hydroxyltoluene (BHT) should be replaced with natural antioxidants due to their proven toxicity $(\mathrm{Li}$ et al., 2007 \& Qi et al., 2005).

The aim of this study was to investigate the crude methanolic extract obtained from the Egyptian Ulva lactuca and its different fractions using phytochemical and chromatographic methods and evaluate their in vitro antioxidant and antiinflammatory properties in order to identify and utilized effective new sources of antioxidants of natural origin.

\section{Experimental}

\subsection{Chemicals}

All reference standards were purchased from Sigma Chemical Co. (St. Louis, Mo, USA). The solvents used for chromatographic assay were of HPLC grade. Other solvents and all chemicals were of analytical reagent (AR) grade.

\subsection{Algae collection, extraction and fractionation:}

The green algae (Ulva lactuca) were collected in October from Abu Kir beach, Alexandria coast, Egypt. The algae were identified by Prof. Dr. Mohamed Saad Abd El -Kareem, Professor of Phycology, Botany and Microbiology Department, Faculty of Science, Alexandria University, Egypt. A voucher specimen (\#9012) was deposited in the Herbarium of the Department of Pharmacognosy, Faculty of Pharmacy, Alexandria University, for future reference. The algae were washed with tap water then left to dry in shade for two days. $1.5 \mathrm{~kg}$ of the dried algae were soaked in 5L methanol for one week, then filtrated, and the process was repeated three times till exhaustion. The filtrates were collected together and the solvent was evaporated using rotary evaporator at $50{ }^{\circ} \mathrm{C}$ (Büchi, Switzerland) to yield $120 \mathrm{~g}$ dried crude extract. The extract was fractionated using hydroalcoholic method using; light petroleum $(0.5 \mathrm{~L} \times 2)$, methylene chloride $(0.5 \mathrm{~L} \times 3)$, ethyl acetate $(0.5 \mathrm{~L} \times 3)$ and $n$ butanol $(0.5 \mathrm{~L} \times 2)$ consequently. These fractions were concentrated using rotary evaporated then lyophilized (Dynavac, FD12, Belmont, Australia) to give the dried fractions.
Table 1: Weight of each fraction from Ulva lactuca

\begin{tabular}{ll}
\hline Fraction type/Extract & $\begin{array}{l}\text { Extract weight } \\
\text { [g /500 g dried } \\
\text { algae] }\end{array}$ \\
\hline Total methanolic extract & 120 \\
Light petroleum fraction & 17.6 \\
$\mathrm{CH}_{2} \mathrm{Cl}_{2}$ fraction & 6.98 \\
Ethyl acetate fraction & 0.1 \\
$n$-butanol fraction & 27.5 \\
Aqueous fraction & 55.36 \\
\hline
\end{tabular}

\subsection{Phytochemical investigation of Ulva lactuca extract:}

Total phenolics were assessed by FolinCiocalteu method (Alhakmani et al., 2013). Total flavonoid was analyzed by aluminum chloride colorimetric method (Pourmorad et al., 2006). Total alkaloid was determined by Bromocresol green method (John et al., 2014). Total carbohydrates and total lipids were measured by anthrone method (Ludwig and Goldberg, 1956) and sulphuric acid and phosphovanilin (SPVA) method (McMahon et al., 2014). Finally, Amino acid content and total protein were assayed using ninhydrin and modified Folin-Lowary methods (Nobel and Bailey, 2009), respectively.

\subsection{In vitro biological screening}

2.4.1. Determination of DPPH antioxidant activity:

Ulva extracts, $100 \mathrm{uL}$ each, were added to 100 $\mathrm{uL}$ methanolic solution of diphenyl picryl hydrazyl; DPPH $(100 \mu \mathrm{M})$. After $15 \mathrm{~min}$ at room temperature, the absorbance was recorded at 517 $\mathrm{nm}$. The experiment was repeated for three times. Vitamin C was used as a positive control. IC50 values denote the concentration of sample, which is required to scavenge $50 \%$ of DPPH free radicals (Sharma and Bhat, 2009).

\subsubsection{Determination of NO radical scavenging activity:}

Sodium nitroprusside $(10 \mathrm{mM}, 100 \mathrm{uL})$, in phosphate-buffered saline, was mixed with 100 $\mathrm{uL}$ of each extract/fraction, dissolved in water, and incubated at room temperature for $150 \mathrm{~min}$. After the incubation period, $0.5 \mathrm{ml}$ of Griess reagent was added. The absorbance of the chromophore formed was read at $546 \mathrm{~nm}$. Quercetin was used as positive control (Marcocci et al., 1994). 


\subsubsection{Determination of anti-Inflammatory activity}

Anti-inflammatory activity of each extract/fractions was assessed by Human Red Blood Corpuscles (HRBCs) membrane stabilizing method (Oyedapo et al., 2010) with slight modifications. The blood was collected from healthy human volunteer who had not taken any anti-inflammatory drugs for 2 weeks prior to the experiment and transferred to the heparinized centrifuge tubes and centrifuged at 3,000 rpm. The packed cells were washed with isosaline and a $10 \%$ suspension in normal saline was made. Diclofenac potassium $(50 \mathrm{mcg} / \mathrm{ml})$ was used as a standard. The reaction mixture $(4-5 \mathrm{ml})$ consisted of $2 \mathrm{ml}$ hypotonic saline $(0.25 \% \mathrm{w} / \mathrm{v}$ $\mathrm{NaCl}$ ), $1 \mathrm{ml} 0.15 \mathrm{M}$ phosphate buffer (pH 7.4), $1 \mathrm{ml}$ of test solution $(1 \mathrm{mg} / \mathrm{ml})$ in normal saline and 0.5 $\mathrm{ml} 10 \%$ HRBC in normal saline. For control, $1 \mathrm{ml}$ of isotonic saline was used instead of the test solution. The mixtures were incubated at $56^{\circ} \mathrm{C}$ for $30 \mathrm{~min}$ and cooled at running tap water, centrifuge at $3000 \mathrm{rpm}$ for $20 \mathrm{~min}$. The absorbance of supernatant was read at $560 \mathrm{~nm}$ using visible Spectrophotometer (UV-1201 Shimadzu spectrometer). The experiment was performed in triplicates. The control represents $100 \%$ lyses. The Percentage membrane stabilization was calculated using the following formula;

$\%$ Inhibition of haemolysis $=100 \times$ [Absorbance of control - Absorbance of test]/ Absorbance of control.

\subsection{Experimental statistical analyses}

All data were expressed as the mean \pm standard deviation (SD). The differences were considered to be statistically significant at $p<0.05$. Statistical analysis was performed using the unpaired Student's $t$-test and one-way analysis of variance (ANOVA) using primer of Biostatistics (Version 5) software program.

\subsection{Quantitative determination of Ulva lactuca water fraction contents by high performance liquid chromatography (HPLC)}

Analysis of the water fraction of Ulva Lactuca extract was carried out on an Agilent-1100 HPLC system equipped with a quaternary gradient pump unit, ultra violet (UV) detector at a wave length of $320 \mathrm{~nm}$ and the analytical column was Zorbax Eclipse XDB-C18 (150 x $406 \mathrm{~mm}, 5 \mu \mathrm{m}$ particle size). Column (Agilent, Santa Clara, CA, USA) was used. Elution was carried out at a flow rate of $0.075 \mathrm{ml} / \mathrm{min}$ at $23^{\circ} \mathrm{C}$. The mobile phase used was $8 \%$ acetonitrile, $22 \%$ isopropyl alchohol and $70 \%$ formic acid solution (1\%). All reference standards and sample were dissolved in distilled water $(1 \mathrm{mg} / \mathrm{ml})$ and were filtered through 0.22 $\mu \mathrm{m}$ syringe filter prior to HPLC analysis. The injection volume was $20 \mu \mathrm{l}$. The results were calculated by measuring the chromatographic peak area. Ulva water fraction identification was made by comparing the relative retention times of sample peaks with those of the reference standards.

\section{Result and Discussion}

Bioactivity of Ulva Lactuca methanolic extract and its fractions were tested to select the most active one. Table1 \& Figure 1showed the yield that obtained from each fraction. The phytochemical investigation quantify lipid, protein, amino acid, carbohydrate, total phenolic, alkaloid and flavonoid content (Table 2).

Table 2: Quantitative phytochemical Screening of Ulva lactuca.

\begin{tabular}{|c|c|c|c|c|c|c|c|}
\hline Extract & $\begin{array}{c}\text { Lipids } \\
\text { (g/100g } \\
\text { extract) }\end{array}$ & $\begin{array}{l}\text { Proteins } \\
\text { (g/100 g } \\
\text { extract) }\end{array}$ & $\begin{array}{c}\text { Amino- } \\
\text { acids } \\
\text { (mg/100g } \\
\text { extract) }\end{array}$ & $\begin{array}{c}\text { Carbohydrates } \\
\text { (g/100 g } \\
\text { extract) }\end{array}$ & $\begin{array}{c}\text { Phenolics } \\
\text { (g/100 g } \\
\text { extract) }\end{array}$ & $\begin{array}{l}\text { Alkaloids } \\
\text { (g/100 g } \\
\text { extract) }\end{array}$ & $\begin{array}{c}\text { Flavonoids } \\
\text { (mg/ 100 g } \\
\text { extract) }\end{array}$ \\
\hline $\begin{array}{c}\text { Light } \\
\text { Petroleum }\end{array}$ & $56.8 \pm 16$ & $3 \pm 0.016$ & 0 & $0.4 \pm 0.02$ & $11.8 \pm 0.2$ & $6 \pm 1.3$ & $2.4 \pm 0.05$ \\
\hline $\mathrm{CH}_{2} \mathrm{Cl}_{2}$ & $30 \pm 11$ & $3.3 \pm 0.022$ & 0 & $0.93 \pm 0.15$ & $11.6 \pm 0.3$ & $8.4 \pm 0.7$ & 0 \\
\hline $\begin{array}{l}\text { Ethyl } \\
\text { Acetate }\end{array}$ & $94.7 \pm 26$ & $3.2 \pm 0.036$ & $84.1 \pm 12$ & $0.47 \pm 0.03$ & $11.9 \pm 0.5$ & $4.3 \pm 1.6$ & $0.03 \pm 0.003$ \\
\hline Butanol & 0 & $2.9 \pm 0.03$ & $120 \pm 10$ & $0.52 \pm 0.09$ & $9.8 \pm 0.4$ & 0 & $0.05 \pm 0.001$ \\
\hline Water & 0 & $2.6 \pm 0.18$ & $400 \pm 23$ & $0.44 \pm 0.06$ & $9.5 \pm 0.9$ & 0 & 0 \\
\hline
\end{tabular}

Each value is the mean \pm SD of triple determinations.

Within each column, values with the same letter are significantly different at $P<0.05$. 
Table 3: The antioxidants, radical scavenging and anti-inflammatory activities of different algae fractions at concentration of $2 \mathrm{mg} / \mathrm{ml}$ :

\begin{tabular}{lccc}
\hline \multicolumn{1}{c}{ Extract/Fractions } & DPPH scavenging \% & NO scavenging \% & Haemolysis-Prevention \% \\
\hline Crude extract & 60 & 33 & 19 \\
Light Petroleum & 33 & 33 & 29 \\
$\mathbf{C H}_{\mathbf{2}} \mathbf{C l}_{2}$ & 36 & 37 & 22 \\
Ethyl acetate & 36 & 23 & 12 \\
Butanol & 37 & 30 & 13 \\
Water fraction & 44 & 38 & 15 \\
\hline
\end{tabular}

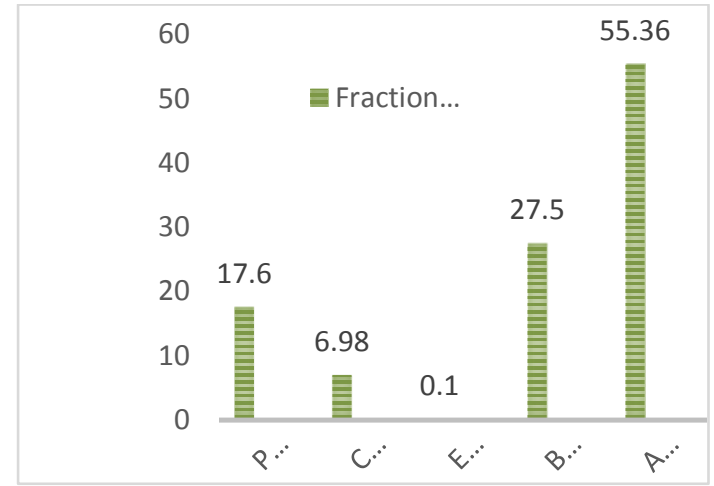

Figure 1: Percentage weight of each fraction

Table 4: Quantitative determination of phenolic content of Ulva lactuca aqueous extract using HPLC data

\begin{tabular}{lc}
\hline \multicolumn{1}{c}{ Compounds } & $\begin{array}{c}\text { Aqueous } \\
\text { extract } \\
\text { content }\end{array}$ \\
\hline Chlorogenic acid (mg/l) & 64.355 \\
Caffeic acid & 50.52 \\
3,4-Dicaffeoyl quinic acid & 34.75 \\
3,5-Dicaffeoyl quinic acid & 110.12 \\
4,5 dicaffeoyl quinic acid & 42.922 \\
Galic acid (mg/ml) & 13.354 \\
Rutin & 3.557 \\
Tanic acid (mg/ml) & 4.63 \\
Quercetin & 1.1 \\
Retinol ug/l & 258.62331 \\
\hline
\end{tabular}

Proteins, carbohydrates and phenolic compounds were found in all fractions. Other phytochemicals were varied in their presence or absence from one fraction to another.

All green alga fractions showed antioxidants activity where the highest one was the water fraction (Table 3). The antioxidant and antiinflammatory activities are concentration dependent where $2 \mathrm{mg} / \mathrm{ml}$ of each one showed the maximum activity peak. DPPH scavenging activity revealed that the most powerful antioxidant was the crude extract followed by its water fraction. NO scavenging test revealed that water fraction was the most potent fraction. Overall, among the tested fractions, water fraction is the most active one so it was chosen as a candidate for further chromatographic study.

Water fraction HPLC analysis (Table 4) revealed the presence of phenolic active constituents in high content acting to increase its antioxidant bioactivity.

\section{Conclusion}

Seaweeds can be excellent sources that could provide the basis of a new therapeutic agent. The results of this study suggest that Ulva lactuca water fraction could be a promising source for the treatment of infectious diseases and oxidative stress related disorders because they are rich in phenolic constituents, offering a potential use as antioxidant candidate.

\section{Conflict of interest}

The authors have no conflict of interest to declare.

\section{Ethical approval}

Not applicable. 


\section{Acknowledgements}

The study received financial support from Alexandria University Research Fund (AURF), Egypt, Grant number (ALEX REP, 2011- 2012).

\section{References}

Alam, S. S., Abd El-Kader, H. A. M., Abd ElRahim, A.H., Hamed, S. M., Saber, A. A. 2016. The Protective Role of Ulva lactuca Against Genotoxic and Biochemical Effects Induced by $\gamma$-Irradiation in Rats. Int. J. Pharm. Sci. Rev. Res. 37(2), 40-48

Alhakmani F., Kumar, S. and Khan, S. A. 2013. Estimation of total phenolic content, invitro antioxidant and anti-inflammatory activity of flowers of Moringaoleifera. Asian Pac J Trop Biomed. 3(8), 623-627.

Apaydın, G., Aylıkcı, V., Cengiz, E., Saydam, M., Küp, N., and Tiraşoğlu, E. 2010. Analysis of Metal Contents of Seaweed (Ulva lactuca) from Istanbul, Turkey by EDXRF. Turkish Journal of Fisheries and Aquatic Sciences. 10, 215-220.

Cooke, M. S., Evans, M. D., Mistry, N. and Lunec, J. 2002. Role of dietary antioxidants in the prevention of in vivo oxidative DNA damage. Nut. Res. Rev. 15,19-41.

Delgado-Roche, L., Rodeiro, I., Riera, M., Herrera, J. A., Venturi, I., Hernández, Y., ... Paz, M. T. 2019). Chemoprotective effects of Ulva lactuca (green seaweed) aqueous-ethanolic extract against subchronic exposure to benzo(a)pyrene by CYP1A1 inhibition in mice. Phytotherapy Research.33(4), 958-967. https://doi.org/10.1002/ptr.6289

El-Baky, H., Farouk, K., Gamal, S. 2008. Evaluation of Marine Alga Ulva lactuca L. as A Source of Natural Preservative Ingredient. American-Eurasian J. Agric. and Environ. Sci., 3(3), 434-444.

John, B., Sulaiman, C. T., George, S. and Reddy, V. R. K. 2014. Spectrophotometric estimation of total alkaloids in selected Justicia species. International Journal of Pharmacy and Pharmaceutical Sciences. 6(5), 647-648.

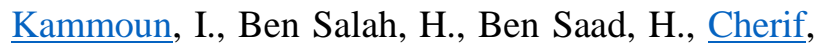
B., Droguet, M., Magné, C., Kallel, C., Boudawara, O., Hakim, A., Gharsallah, N., Ben Amara, I. 2018. Hypolipidemic and cardioprotective effects of Ulva lactuca ethanolic extract in hypercholesterolemic mice. Archives of Physiology and Biochemistry. 124 (4), 313-325.

Kim, I. H., Lee, D.G., Lee, S. H., Ha, J.M., Ha, B.J., Kim, S.K., Lee, J.H. 2007. Antibacterial Activity of Ulva lactuca against MethicillinResistant Staphylococcus aureus (MRSA). Biotechnology and Bioprocess Engineering.12(5),579-582.

\section{https://doi.org/10.1007/BF02931358}

Li, A. H., Cheng, K., Wong, C., Fan, K. W., Chen, F., Jiang, Y. 2007. Evaluation of antioxidant capacity and total phenolic content of different fractions of selected microalgae. Food Chem. 102, 771-776.

Ludwig, T.G. and Goldberg H.J.V. 1956. The anthrone method for the determination of carbohydrates in food and in oral rinsing. Journal of dental research. 35(1), 90-94.

Marcocci, L., Maguire, J., Droylefaix, M., Packert, L. 1994. The Nitric Oxide-Scavenging Properties of Ginkgo Biloba Extract EGb 761. Biochemical and Biophysical Research Communications. 201(2), 748755.https://doi.org/10.1006/bbrc.1994.1764

McMahon, A., Lu, H., Butovich, I.A. 2014. The Spectrophotometric Sulfo-Phospho-Vanillin Assessment of Total Lipids in Human Meibomian Gland Secretions. Lipids. 48(5), 513-525

Noble,J. E. and Bailey, M. J. 2009. Quantitation of protein. Methods in enzymology . 463,73-95

Oyedapo, O., Akinpelu, B. A., Akinwunmi, K. F., AdeyinkaM. O., Sipeolu F. O. 2010. Red blood cell membrane stabilizing potentials of extracts of Lantana camara and its fractions. International Journal of Plant Physiology and Biochemistry. 2(4), 46-51.

Pourmorad, F., Hosseinimehr, J., Shahabimajd, N. 2006. Antioxidant activity, phenol and flavonoid contents of some selected Iranian medicinal plants. African Journal of Biotechnology. 5, 1142-1145.

Qi, H., Zhao, T., Zhang, Q., Li, Z., Zhao, Z., Xing, R. 2005. Antioxidant activity of different molecular weight sulfated polysaccharides from 
Ulva pertusa Kjellm (Chlorophyta). Appl. Phycol. 17,527-534.

Saritha, K., Mani, A. E., Priyalaxmi, M., Patterson, J. 2013. Antibacterial activity and biochemical constituents of seaweed ulva lactuca. Global Journal of Pharmacology. 7(3),276-282.

https://doi.org/10.5829/idosi.gjp.2013.7.3.75156

Sharma, O. and Bhat,T. 2009. DPPH antioxidant assay revisited. Food Chemistry. 113(4),1202-1205.

https://doi.org/10.1016/j.foodchem.2008.08.008

Thanh, T. T. T., Quach, T. M. T., Nguyen, T. N.,
Vu Luong, D., Bui, M. L., Tran, T. T. Van. 2016. Structure and cytotoxic activity of ulvan extracted from green seaweed Ulva lactuca. International Journal of Biological Macromolecules. 93, 695-702.

https://doi.org/10.1016/j.ijbiomac.2016.09.040

Yaich, H., Garna, H., Besbes, S., Paquot, M., Blecker, C., Attia, H. 2011. Chemical composition and functional properties of Ulva lactuca seaweed collected in Tunisia. Food Chemistry.128(4), 895-901.

https://doi.org/10.1016/j.foodchem.2011.03.114 